NASA/TM-2002-211874

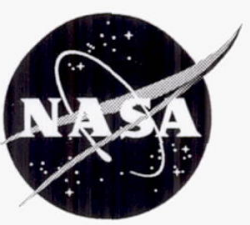

\title{
High Performance Power Module for Hall Effect Thrusters
}

Luis R. Piñero

Glenn Research Center, Cleveland, Ohio

Peter Y. Peterson

QSS Group, Inc., Cleveland, Ohio

Glen E. Bowers

Akima Corporation, Fairview Park, Ohio 
Since its founding, NASA has been dedicated to the advancement of aeronautics and space science. The NASA Scientific and Technical Information (STI) Program Office plays a key part in helping NASA maintain this important role.

The NASA STI Program Office is operated by Langley Research Center, the Lead Center for NASA's scientific and technical information. The NASA STI Program Office provides access to the NASA STI Database, the largest collection of aeronautical and space science STI in the world. The Program Office is also NASA's institutional mechanism for disseminating the results of its research and development activities. These results are published by NASA in the NASA STI Report Series, which includes the following report types:

- TECHNICAL PUBLICATION. Reports of completed research or a major significant phase of research that present the results of NASA programs and include extensive data or theoretical analysis. Includes compilations of significant scientific and technical data and information deemed to be of continuing reference value. NASA's counterpart of peerreviewed formal professional papers but has less stringent limitations on manuscript length and extent of graphic presentations.

- TECHNICAL MEMORANDUM. Scientific and technical findings that are preliminary or of specialized interest, e.g., quick release reports, working papers, and bibliographies that contain minimal annotation. Does not contain extensive analysis.

- CONTRACTOR REPORT. Scientific and technical findings by NASA-sponsored contractors and grantees.
- CONFERENCE PUBLICATION. Collected papers from scientific and technical conferences, symposia, seminars, or other meetings sponsored or cosponsored by NASA.

- SPECial pUblication. Scientific, technical, or historical information from NASA programs, projects, and missions, often concerned with subjects having substantial public interest.

- TECHNICAL TRANSLATION. Englishlanguage translations of foreign scientific and technical material pertinent to NASA's mission.

Specialized services that complement the STI Program Office's diverse offerings include creating custom thesauri, building customized databases, organizing and publishing research results ... even providing videos.

For more information about the NASA STI Program Office, see the following:

- Access the NASA STI Program Home Page at http://www.sti.nasa.gov

- E-mail your question via the Internet to help@sti.nasa.gov

- Fax your question to the NASA Access Help Desk at 301-621-0134

- Telephone the NASA Access Help Desk at 301-621-0390

- Write to:

NASA Access Help Desk

NASA Center for AeroSpace Information 7121 Standard Drive Hanover, MD 21076 
NASA/TM-2002-211874

\section{High Performance Power Module for Hall Effect Thrusters}

Luis R. Pinero

Glenn Research Center, Cleveland, Ohio

Peter Y. Peterson

QSS Group, Inc., Cleveland, Ohio

Glen E. Bowers

Akima Corporation, Fairview Park, Ohio

Prepared for the

38th Joint Propulsion Conference and Exhibit cosponsored by AIAA, ASME, SAE, and ASEE

Indianapolis, Indiana, July 7-10, 2002

National Aeronautics and

Space Administration

Glenn Research Center 
Available from

NASA Center for Aerospace Information National Technical Information Service 5285 Port Royal Road Springfield, VA 22100

Hanover, MD 21076

Available electronically at http://gltrs.grc.nasa.gov 


\title{
HIGH PERFORMANCE POWER MODULE FOR HALL EFFECT THRUSTERS
}

\author{
Luis R. Piñero \\ National Aeronautics and Space Administration \\ Glenn Research Center \\ Cleveland, Ohio 44135 \\ Peter Y. Peterson ${ }^{\dagger}$ \\ QSS Group, Inc. \\ Cleveland, Ohio 44135 \\ Glen E. Bowers ${ }^{\ddagger}$ \\ Akima Corporation \\ Fairview Park, Ohio 44126
}

\begin{abstract}
Previous efforts to develop power electronics for Hall thruster systems have targeted the 1 to $5 \mathrm{~kW}$ power range and an output voltage of approximately $300 \mathrm{~V}$. New Hall thrusters are being developed for higher power, higher specific impulse, and multi-mode operation. These thrusters require up to $50 \mathrm{~kW}$ of power and a discharge voltage in excess of $600 \mathrm{~V}$. Modular power supplies can process more power with higher efficiency at the expense of complexity. A $1 \mathrm{~kW}$ discharge power module was designed, built and integrated with a Hall thruster. The breadboard module has a power conversion efficiency in excess of 96 percent and weighs only $0.765 \mathrm{~kg}$. This module will be used to develop a $\mathrm{kW}$, multi-kW, and high voltage power processors.
\end{abstract}

\section{Introduction}

Hall effect thrusters (HET) provide the advantage of high thrust to power ratio at high specific impulse compared to other electrostatic devices. They are attractive for Earth orbital and deep space applications. ${ }^{1-5}$ NASA Glenn Research Center (NASA-GRC) is currently developing new Hall thruster concepts including multi-mode and high power engines. ${ }^{6}$ In-house efforts concentrate on the development of the NASA-173M V.2 high voltage thruster and the NASA-457M high power thruster. ${ }^{7-10}$

NASA-GRC is simultaneously developing power processing technologies that facilitate the development of a high power/high voltage power processing units (PPUs). In state-of-the-art (SOA) HET systems, the PPU is the most complex, expensive, and massive component. For high power applications, efficiency is a

\footnotetext{
* Electrical Engineer, On-Board Propulsion Branch, Senior Member AIAA.

† Engineering III Intern, Member AIAA.

$\ddagger$ Electronic System Mechanic.
}

critical requirement for the PPU as a small reduction in efficiency could result in a large amount of additional waste heat to be rejected by the spacecraft, increasing thermal radiator requirements. This could have negative impact on a spacecraft as SOA radiator technologies have a specific mass exceeding $10 \mathrm{~kg} / \mathrm{kW}^{11}$

A high efficiency, lightweight, $1 \mathrm{~kW}$ discharge power module was developed. This power module will be used to develop a $\mathrm{kW}$-class PPU capable of operating in high voltage or high current modes for the NASA-173M V.2 thruster. In addition, the design will be used as the foundation for a multi-kW design targeted to a high power thruster like the NASA-457M. This paper documents the design and performance characteristics of the $1 \mathrm{~kW}$ discharge power module. Also, it presents the results of integration testing with a NASA-120M Hall thruster. 


\section{Thruster Interface and PPU Specifications}

A typical HET system consists of a thruster, PPU, and propellant feed system. The PPU is the most complex, heaviest and most expensive of all three components. A typical HET PPU, as shown in Figure 1, includes a voltage regulated discharge supply, which provides power for ionizing the xenon propellant and accelerating ions. The inner and outer magnets supplies are current regulated supplies that control the magnetic field in the HET. The cathode heater and keeper supplies provide constant current to the cathode heater to raise its temperature and for starting and maintaining cathode emission. Most PPUs also include auxiliary power supplies for control and feed system functions.

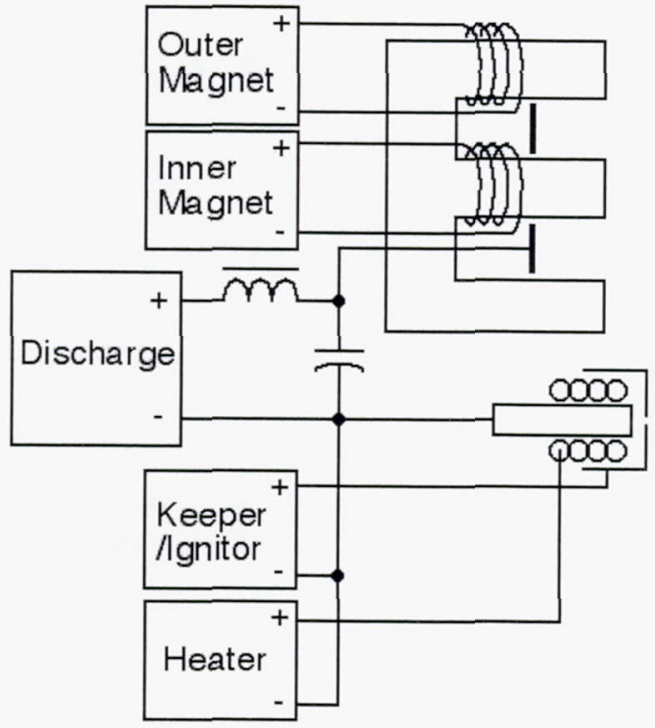

Figure 1. Electrical connections of typical HET PPU.

High power PPUs pose unique challenges to the designer. High current and voltage are difficult to manipulate efficiently using power semiconductor devices. As seen in many SOA $\mathrm{kW}$-class Hall thruster PPUs, it is usually advantageous to use a modular approach. ${ }^{12-16}$ In this type of design, lower power modules are connected either in series and/or parallel to obtain higher total power. This reduces the amount of current processed by individual semiconductors, including diodes and MOSFETs, and also reduces the required voltage rating for diodes and capacitors. The result of this is lower power losses yielding higher PPU efficiency. Another advantage of this type of architecture is that the switching of the MOSFETs in the individual modules can be staggered to reduce input and output ripples. This reduces filter requirements and could result in mass reduction for the PPU. In addition, modular designs allow the use of redundant modules for increased PPU reliability.

In a Hall thruster system, most of the power is processed by the discharge power supply. For example, on the NASA-173M thruster, discharge power is more than 96 percent of the total thruster power for most operating conditions. ${ }^{7-8}$ The reminder of the power is used by the magnets. Topology selection for the discharge supply is critical to obtain high overall PPU efficiency.

A summary of electrical specifications for the discharge power module is shown in Table 1. An input voltage range of 80 to $120 \mathrm{~V}$ was selected for this design. This is based on the assumption that a spacecraft that would use a high power HET system will have an unregulated, high voltage power bus. A nominal output voltage of $300 \mathrm{~V}$ was chosen for the output as many HET operate at this level. For higher voltage applications additional modules can be connected in series.

Table 1. Power Module Design Specifications

\begin{tabular}{|c|c|c|}
\hline & Nominal & Range \\
\hline Input Voltage & $100 \mathrm{~V}$ & $80-120 \mathrm{~V}$ \\
\hline Output Voltage & $300 \mathrm{~V}$ & $100-350 \mathrm{~V}$ \\
\hline Output Current & $3.0 \mathrm{~A}$ & $0.5-3.5 \mathrm{~A}$ \\
\hline Output Power & $\leq 1.0 \mathrm{~kW}$ & - \\
\hline Output Ripple & $\leq 5 \%$ & - \\
\hline Regulation & $\leq 1 \%$ & - \\
\hline Efficiency & $\geq 94 \%$ & - \\
\hline
\end{tabular}

\section{Discharge Power Module Design}

At kW power levels, a full-bridge converter topology is very attractive. The advantages of this topology are low voltage stress on the switching transistors and good transformer utilization. In addition, in combination with phase-shift pulse width modulation (PWM) 
control, "soft-switching" techniques can be used to reduce losses. ${ }^{17}$ Even though this technology has been used in the past for electric propulsion applications, the scope of this effort was to validate a simpler, more efficient, and lighter design. ${ }^{18-20} \quad$ Figure 2 shows a simplified schematic of this topology. A breadboard power module, as shown in Figure 3 , was build to validate the electrical design.

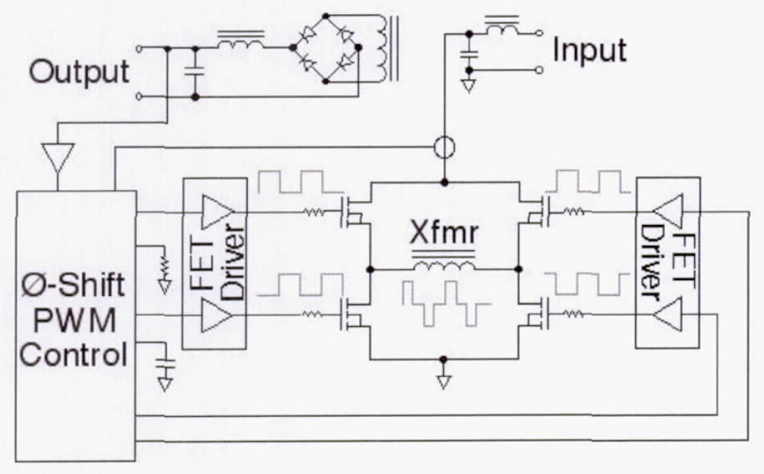

Figure 2. Block diagram of power module.

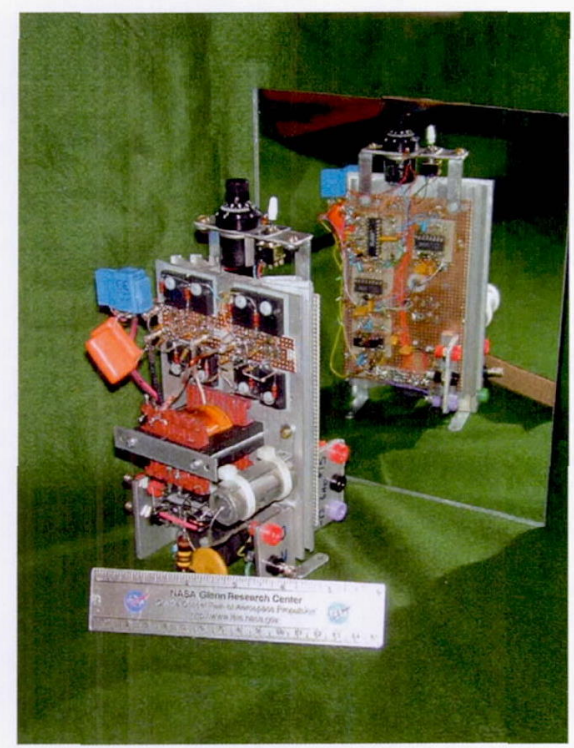

Figure 3. Breadboard discharge power module.

A switching frequency of $50 \mathrm{kHz}$ was chosen as a compromise between mass and efficiency. The power transformer and filter inductors were built using ferrite cores for their low mass density and low core losses. A step up ratio of $1: 3$ was used to step up the nominal input voltage of $100 \mathrm{~V}$ up to $300 \mathrm{~V}$. Litz wire and winding techniques were used for the power transformer to reduce parasitics, skin and proximity effects. The MOSFET power stage and control circuitry were built using power and ground planes to reduce parasitic loop inductance and noise. The results of the efforts to reduce parasitics are reflected in the absence of transients in the primary voltage and current waveforms shown in Figure 4.

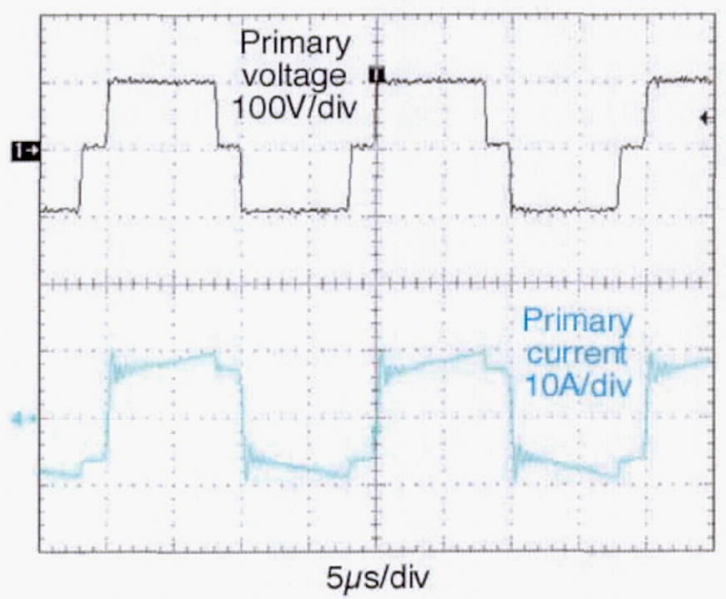

Figure 4. Primary voltage and current for the discharge power module.

Phase-shift PWM was implemented using a UCC3895 controller. This integrated circuit provides the necessary gate drives for the MOSFETs by phase shifting one half of the bridge with respect of the other. For this application, peak current mode control was used for its good short circuit protection. In addition, this controller provides other functions that are advantageous for this application. The current limit function limits the maximum current into the power module. In the case of an over-current condition, a "soft-stop" function disables the output for a programmable period of time and then restarts operation. Finally, a soft-start function ramps up the output at an adjustable rate which can be used to limit starting transients when starting a thruster.

Gate drives were implemented with IR2110 high and low drivers using a bootstrap circuit to isolate the floating MOSFET. Ultra-fast, ultrasoft recovery diodes with typical reverse recovery of 18 ns were used to reduce reverse 
recovery transients and ringing which in addition reduce snubbing requirements. The output filter, which consists of an LC low-pass filter, was designed to meet the output ripple specification.

Figure 5 shows a picture of a power module built on a printed circuit board (PCB). This version of the power module has the advantage of lower noise and transients from parasitics by using a multi-layer PCB. Also, it provides repeatability between multiple modules to be used in a high power unit. The module built on a PCB measures $22.5 \mathrm{~cm}$ by $21.0 \mathrm{~cm}$ and weighs $0.765 \mathrm{~kg}$. The design uses only 102 components with a combined weight of $0.516 \mathrm{~kg}$.

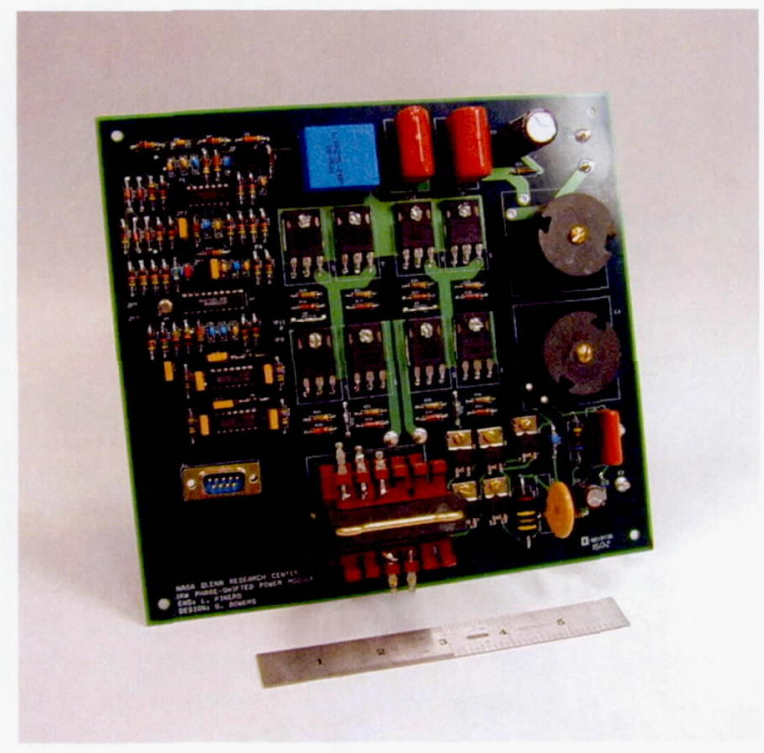

Figure 5. PCB Version of discharge power module.

\section{$\underline{\text { Resistive Load Tests }}$}

The discharge power module was characterized using a resistive load at power levels from 0.1 to $1.0 \mathrm{~kW}$ and voltages of 240 and $300 \mathrm{~V}$. Voltages and current were measured using a high bandwidth power analyzer. Efficiency was defined as the ratio of output to input power without including housekeeping power.

Figure 6 shows the efficiency as a function of output power for $300 \mathrm{~V}$ and $240 \mathrm{~V}$ output. Efficiency was better or equal to 96.0 percent at
$300 \mathrm{~V}$ output, nominal $100 \mathrm{~V}$ input, and a power range of 0.3 to $1.0 \mathrm{~kW}$. For a $240 \mathrm{~V}$ output, efficiency was higher than 93.7 percent for power levels from 0.1 to $0.7 \mathrm{~kW}$.

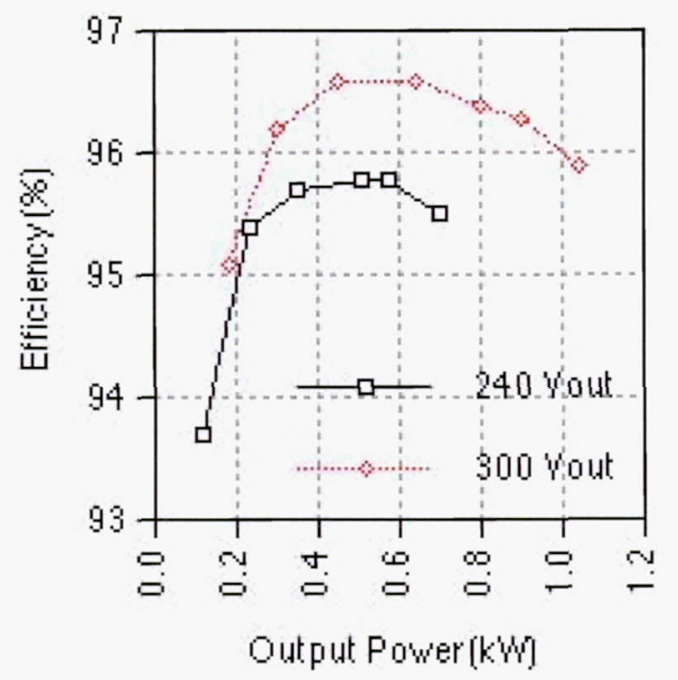

Figure 6. Efficiency as a function of output power at $300 \mathrm{~V}$ and $240 \mathrm{~V}$ at $100 \mathrm{~V}$ input.

Efficiency as a function of input voltage, with an output load of $100 \Omega$, is shown in Figure 7. For a $300 \mathrm{~V}$ and $240 \mathrm{~V}$ outputs, for any input voltage, efficiency was better than 95.7 percent and 95.0 percent, respectively.

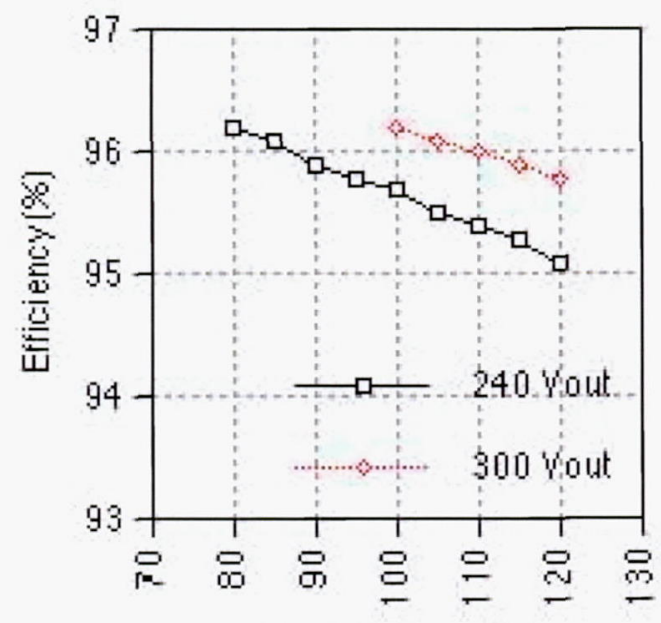

Input Yoltage ['v]

Figure 7. Efficiency as a function of input voltage at $300 \mathrm{~V}$ and $240 \mathrm{~V}$ into $100 \Omega$ load. 
Load and line regulation were tested by adjusting a resistive load or the input voltage at nominal operating conditions. They were defined as the ratio of output voltage change to nominal output voltage. For both cases, regulation was measured to be better than 0.2 percent. Also, a high-load and short circuit tests were conducted to verify operation of the current limit and soft-stop function. This was implemented by reducing the load resistance below nominal levels and by mechanically shorting the output. The power module survived both tests and the current limit and soft-stop functions performed properly.

Finally, the voltage feedback loop of the power module was tested for stability. The results of these tests are show in Figure 8. The power module has a bandwidth approximately $4.3 \mathrm{kHz}$, gain margin of $15 \mathrm{~dB}$ and phase margin of 73 degrees. This is enough to guarantee stability and provide good transient response.

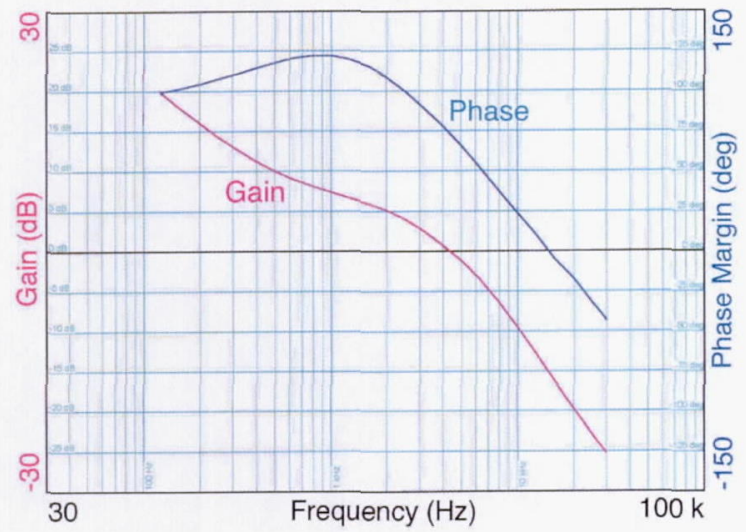

Figure 8. Power module feedback loop stability measurements.

\section{Thruster Integration Tests}

Thruster integration tests were conducted using a $3 \mathrm{~kW}$-class, laboratory model NASA-120M Hall thruster. This thruster was developed by the NASA GRC Hall thruster program to serve as a test-bed for erosion diagnostics, capacitive discharge operation studies, and for investigation of the influence of channel parameters on operation. The thruster, depicted in Figure 9, has an outer diameter of $120 \mathrm{~mm}$.
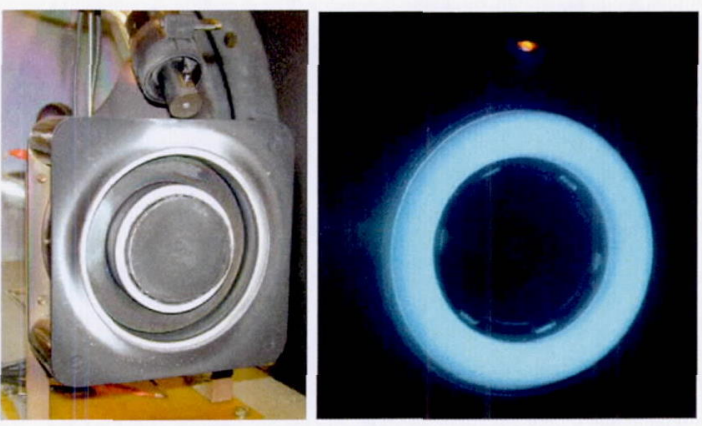

Figure 9. NASA-120M, 3-kW class laboratory model Hall thruster.

The NASA-120M performance is comparable to existing Hall thrusters of similar size. Table 2 shows the measured performance characteristics of the NASA-120M for operating conditions used in this experiment. The hollow cathode used for this test was manufactured by NASA GRC and was designed to operate up to $9.0 \mathrm{~A}$. The cathode was operated at a mass flow rate of $0.8 \mathrm{mg} / \mathrm{s}$.

Table 2. NASA-120M thruster operating conditions

\begin{tabular}{|c|c|c|c|c|c|c|}
\hline Case & $\begin{array}{c}\text { Vdis } \\
{[\mathrm{V}]}\end{array}$ & $\begin{array}{c}\text { Idis } \\
{[\mathrm{A}]}\end{array}$ & $\begin{array}{c}\text { Pdis } \\
{[\mathrm{W}]}\end{array}$ & $\begin{array}{c}\text { Anode } \\
{[\mathrm{mg} / \mathrm{s}]}\end{array}$ & $\begin{array}{c}\text { Isp } \\
{[\mathrm{sec}]}\end{array}$ & $\begin{array}{c}\text { Eff } \\
{[\%]}\end{array}$ \\
\hline$(1)$ & 240 & 2.8 & 672 & 3.4 & N/A & N/A \\
\hline$(2)$ & 300 & 2.7 & 810 & 3.4 & 1409 & 41 \\
\hline
\end{tabular}

The thruster was initially run using laboratory power supplies to verify its performance. The starting procedure consisted of starting cathode and main flow and the cathode heater and keeper supplies. After approximately 5 minutes, the cathode started at a $2.0 \mathrm{~A}$ keeper current and the heater was turned off. Then, inner and outer magnet supplies were turned on. Finally, the discharge supply was turned on and slowly adjusted from zero to the operating voltage.

In general, HETs exhibit characteristic discharge current oscillations during operation. The source of these oscillations is ionization phenomena in the discharge chamber. These oscillations have a fundamental frequency in the range of $10^{4} \mathrm{~Hz}$ but also have components in the $10^{6} \mathrm{~Hz}$ 
range. ${ }^{20-22}$ Traditionally, a "matching network" consisting of an LC low pass filter have been used between the thruster and the discharge supply. This filter supplies the thruster the ripple current it requires for start-up and steady-state operation. Also, it attenuates the oscillations into the discharge supply that can cause control instabilities and lead to power supply failure. ${ }^{21-22}$

Figure 10 shows discharge current oscillations on the NASA-120M thruster operating at $300 \mathrm{~V}$ and $2.7 \mathrm{~A}$. For this part of the test, only a $100 \mu \mathrm{F}$ capacitor was used at the vacuum feedthrough since laboratory power supplies usually have over-designed output filters and do not have much difficulty running HETs. The frequency of the oscillations was approximately $25 \mathrm{kHz}$ and the amplitude was in excess of $5.0 \mathrm{~A}$. The large amplitude of the oscillations, compared to other Hall thrusters, was probably caused by operating the thruster at extremely low power. In addition, the magnet supplies were not set at optimum levels to minimize oscillations. Integration was conducted even at these non-optimized conditions as it presents a tougher challenge for the power module.

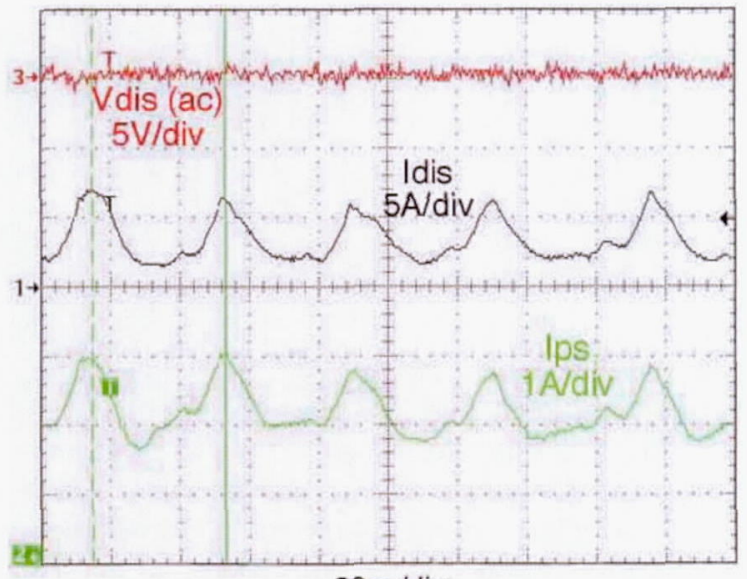

$20 \mu \mathrm{s} / \mathrm{div}$

Figure 10. Oscillations during laboratory power supply operation with the NASA-120M thruster.
The power module was then connected at the discharge input to the thruster. The $100 \mu \mathrm{F}$ capacitor was removed and a matching network, consisting of an LC filter, was installed as shown in Figure 1. The values for the filter components were verified with computer simulation using a current source to model the HET discharge. Values of $10 \mu \mathrm{F}$ and $100 \mu \mathrm{H}$ were selected for the capacitor and the inductor, respectively.

The NASA-120M thruster was operated close to the power module maximum power and a lower power setpoint. Figure 11 show the current and voltage oscillations at the thruster and the module output current. Current oscillations were as high as $7.0 \mathrm{~A}_{p-p}$ or $260 \%$ of the $\mathrm{DC}$ value. Voltage oscillations were approximately $3.0 \mathrm{~V}_{\mathrm{p}-\mathrm{p}}$ or 1.0 percent at $300 \mathrm{~V}$ operation.

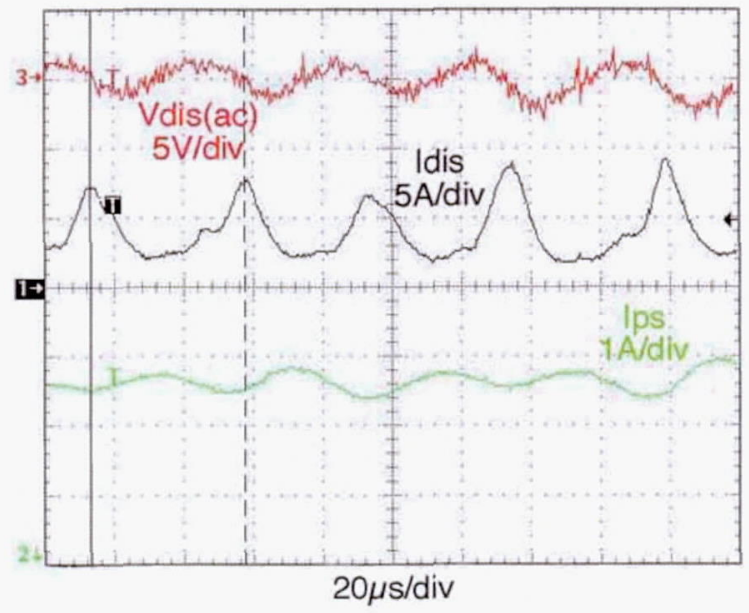

Figure 11. Oscillations during power module operation with the NASA-120M thruster.

The programmable soft-start function that was tested for thruster start-up. It provided a smooth start as shown on Figure 12. The output voltage jumps quickly to about $50 \mathrm{~V}$ where the thruster starts and current starts flowing. From there, the voltage builds-up to $300 \mathrm{~V}$ in approximately $450 \mathrm{~ms}$. Multiple startups were successfully conducted at $300 \mathrm{~V}$ and $240 \mathrm{~V}$ output. 


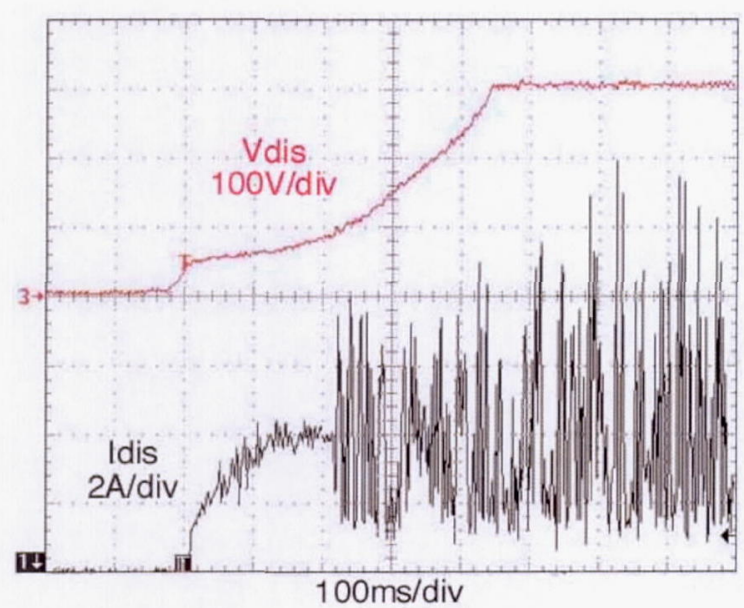

Figure 12. Thruster startup at $300 \mathrm{~V}$ using soft start function.

\section{Conclusions}

A breadboard discharge power module for HETs was designed and fabricated. The module uses a phase-shifted full-bridge topology operating at a switching frequency of $50 \mathrm{kHz}$ to process up to $1.0 \mathrm{~kW}$ of output power. The mass of the power module is only $0.765 \mathrm{~kg}$. Operating at nominal input and output conditions of 100 and $300 \mathrm{~V}$, respectively, efficiencies in excess of 96.0 percent were measured. The discharge power module was successfully integrated with a NASA-120M Hall thruster. The module started and ran the thruster without difficulty even with large discharge current oscillations due to operation at off-nominal conditions.

This design will be used to develop $\mathrm{kW}$-class PPUs by operating multiple modules in either parallel or series to process higher power and/or voltage. It will also be used as foundation for the design of multi-kW PPUs. This design should help reduce the mass of future HET systems and reduce their impact on spacecraft power and thermal system making HET propulsion systems more attractive for orbital and deep space applications.

\section{$\underline{\text { References }}$}

1. Oleson, S.R., "Advanced Hall Electric Propulsion for Future In-Space Transportation," 3rd International Conference on Spacecraft Propulsion, Cannes, France, October, 2000.
2. Oleson, S.R., "Mission Advantages of Constant Power, Variable Isp Electrostatic Thrusters," AIAA-2000-3413, $36^{\text {th }}$ Joint Propulsion Conference, Huntsville, Alabama, July, 2000.

3. Oleson, S.R., "Advanced Electric Propulsion for RLV Launched Geosynchronous Spacecraft," IEPC 99-185, $26^{\text {th }}$ International Electric Propulsion Conference, Kitakyushu, Japan, October, 1999.

4. Oleson, S.R., "Advanced Electric Propulsion For Space Solar Power Satellites," AIAA-992872, $35^{\text {th }}$ Joint Propulsion Conference, June, 1999.

5. Oleson S.R., et al. "Advanced Propulsion for Geostationary Orbit Insertion and North-South Station Keeping," (rev.), Journal of Spacecraft and Rockets, Vol. 34, Number 1, pp. 22-28, 1997.

6. Jankovsky, R.S., et al., "NASA's Hall Thruster Program 2002," AIAA-2002-3675, 38 ${ }^{\text {th }}$ Joint Propulsion Conference, Indianapolis, IN, July 710, 2002.

7. Hofer, R., et al., "A high Specific Impulse Two-Stage Hall Thruster with Plasma Lens Focusing," IEPC-01-036, $27^{\text {th }}$ International Electric Propulsion Conference Proceedings, Pasadena, California, October 15-19, 2001.

8. Hofer, R.R., et al., "The Role of Magnetic Field Topography in Improving the Performance of a High Voltage Hall Thruster," AIAA-2002$4111,38^{\text {th }}$ Joint Propulsion Conference, Indianapolis, Indiana, July 7-10, 2002.

9. Manzella, D., et al., "Laboratory Model $50 \mathrm{~kW}$ Hall Thruster," AIAA-2002-3676, $38^{\text {th }}$ Joint Propulsion Conference, Indianapolis, Indiana, July 7-10, 2002.

10. Manzella, D.H., et al., "High Voltage SPT Performance," AIAA-2001-3774, $37^{\text {th }}$ Joint Propulsion Conference, Salt Lake City, Utah, July 8-11, 2001.

11. Juhasz, A.J., et al., "Parametric Study of Radiator Concepts for a Stirling Radioisotope Power System Applicable to Deep Space Missions," NASA/TP-2000-209676, June 2000. 
12. Skelly, P., et al., "RHETT/EPDM Power Processing Unit," IEPC-97-104, 25 $5^{\text {th }}$ International Electric Propulsion Conference Proceedings, Cleveland, Ohio, August, 1997.

13. Kay, R., et al., "The Development of a 4.5 kW Hall Thruster Propulsion System Power Processing Unit," IEPC-01-333, $27^{\text {th }}$ International Electric Propulsion Conference Proceedings, Pasadena, California, October 1519, 2001.

14. Declercq, H., et al., "Power Processing Unit for Stationary Plasma Thruster," IEPC-99-059, $26^{\text {th }}$ International Electric Propulsion Conference, Kitakyushu, Japan, October, 1999.

15. Pidgeon, D., et al., " $4.5 \mathrm{~kW}$ Hall Thruster Power Processor Development," SAE 1999-011381.

16. "Express/T-160E Flight Test, Delta Critical Design Review" Space Power, Inc., NASA Contract NAS3-97110, May 4-7, 1999.

17. Lee, F.C., "High-Frequency Resonant and Soft-Switching PWM Converters," Virginia Power Electronic Center, 1991, p. 181-278.
18. Hamley, J.A., et al., "Power Electronics Development for the SPT-100 Thruster" IEPC93-044, 23 ${ }^{\text {rd }}$ International Electric Propulsion Conference Proceedings, Seattle, Washington, July, 1993.

19. Tan, F.D., et al., "An Optimum Power Processing Unit for the Hall-Effect Thruster," IECEC-98-224, 33 $3^{\text {rd }}$ Intersociety Energy Conversion Engineering Conference Proceedings, Colorado Springs, Colorado, August 2-6, 1998.

20. Hruby, V., et al., "DC-DC Converter for Hall Thruster Plasma Discharge," IEPC-99-061, 26 $6^{\text {th }}$ International Electric Propulsion Conference, Kitakyushu, Japan, October, 1999.

21. Randolph, T., et al., "The Mitigation of Discharge Oscillations in the Stationary Plasma Thruster," AIAA-94-2857, 30 ${ }^{\text {th }}$ Joint Propulsion Conference, June 27-29, 1994.

22. Petrenko, A.N., et al., "The Problem of Power Processor and Telemetry/Control Unit Design for Stationary Plasma Thruster." 


\section{REPORT DOCUMENTATION PAGE}

Public reporting burden for this collection of information is estimated to average 1 hour per response, including the time for reviewing instructions, searching existing data sources, gathering and maintaining the data needed, and completing and reviewing the collection of information. Send comments regarding this burden estimate or any other aspect of this collection of information, including suggestions for reducing this burden, to Washington Headquarters Services, Directorate for Information Operations and Repor Davis Highway, Suite 1204, Arlington, VA 22202-4302, and to the Office of Management and Budget, Paperwork Reduction Project (0704-0188), Washington, DC 20503.

\begin{tabular}{l|l|l|} 
1. AGENCY USE ONLY (Leave blank) & 2. REPORT DATE & 3. REPORT TYPE AND DATES COVERED
\end{tabular}

\section{TITLE AND SUBTITLE}

September 2002

High Performance Power Module for Hall Effect Thrusters

6. AUTHOR(S)

Luis R. Piñero, Peter Y. Peterson, and Glen E. Bowers

7. PERFORMING ORGANIZATION NAME(S) AND ADDRESS(ES)

National Aeronautics and Space Administration

John H. Glenn Research Center at Lewis Field

Cleveland, Ohio 44135-3191

9. SPONSORING/MONITORING AGENCY NAME(S) AND ADDRESS(ES)

National Aeronautics and Space Administration

Washington, DC 20546-0001
Technical Memorandum
WU-755-B4-05-00

8. PERFORMING ORGANIZATION REPORT NUMBER

E-13556
10. SPONSORING/MONITORING AGENCY REPORT NUMBER

NASA TM-2002-211874

AIAA-2002-3947

\section{SUPPLEMENTARY NOTES}

Prepared for the 38th Joint Propulsion Conference and Exhibit cosponsored by AIAA, ASME, SAE, and ASEE, Indianapolis, Indiana, July 7-10, 2002. Luis R. Piñero, NASA Glenn Research Center; Peter Y. Peterson, QSS Group, Inc., Cleveland, Ohio 44135; and Glen E. Bowers, Akima Corporation, Fairview Park, Ohio 44126. Responsible person, Luis R. Piñero, organization code 5430, 216-977-7428.

\begin{tabular}{|l|l} 
12a. DISTRIBUTION/AVAILABILITY STATEMENT & 12b. DISTRIBUTION CODE
\end{tabular}

Unclassified - Unlimited

Subject Category: 20

Distribution: Nonstandard

Available electronically at http://gltrs.grc.nasa.gov

This publication is available from the NASA Center for AeroSpace Information, 301-621-0390.

13. ABSTRACT (Maximum 200 words)

Previous efforts to develop power electronics for Hall thruster systems have targeted the 1 to $5 \mathrm{~kW}$ power range and an output voltage of approximately $300 \mathrm{~V}$. New Hall thrusters are being developed for higher power, higher specific impulse, and multi-mode operation. These thrusters require up to $50 \mathrm{~kW}$ of power and a discharge voltage in excess of $600 \mathrm{~V}$. Modular power supplies can process more power with higher efficiency at the expense of complexity. A $1 \mathrm{~kW}$ discharge power module was designed, built and integrated with a Hall thruster. The breadboard module has a power conversion efficiency in excess of 96 percent and weighs only $0.765 \mathrm{~kg}$. This module will be used to develop a $\mathrm{kW}$, multi-kW, and high voltage power processors.

\section{SUBJECT TERMS}

Hall thruster; Power converter; Power conditioning; Voltage converters; DC to DC; Power modules STS

\section{SECURITY CLASSIFICATION OF REPORT}

Unclassified
18. SECURITY CLASSIFICATION OF THIS PAGE

Unclassified
19. SECURITY CLASSIFICATION OF ABSTRACT Unclassified
15. NUMBER OF PAGES 14

\section{PRICE CODE}

20. LIMITATION OF ABSTRACT 